\title{
Mechanisms of stimulating activities in banking participation in the development of construction industry and national economy at all
}

\author{
Elena Altukhova1 ${ }^{1, *}$, Maxim Markov $^{2}$, Denis Perepelitsa ${ }^{2}$, and Lazar Badalov ${ }^{3}$ \\ ${ }^{1}$ Plekhanov Russian University of Economics, Department of financial management, 117997, Moscow, Russia \\ ${ }^{2}$ Plekhanov Russian University of Economics, Department of financial markets, 117997, Moscow, Russia \\ ${ }^{3}$ Financial University under the Government of the Russian Federation, Department of World Economy and World Finance, 125993 , \\ Moscow, Russia
}

\begin{abstract}
The development of the real sector is crucial to ensure the growth of the national economy of any state. The main institution working with money in the economy are banks. They serve the cash flows of companies in real sector, and also serve as one of the sources of investment for them, which are provided in the form of bank loans. Given that the task of stimulating the growth of the real sector is not only facing the banking system, but also the economy as a whole, the approach to solving it should be comprehensive and systemic. In this regard, it is especially important to develop a list of measures that provide a differentiated approach to the support system for companies in the real sector of the economy. The implementation of such measures should include the active participation of development institutions, and therefore the active participation of banks in the system of implementation of national projects. Particularly important in this regard is the improvement of legislative regulation of issues of interaction between banks and business entities, as well as the development of new financial instruments that contribute to building up the financial potential of the real sector of the economy. The article analyzes the participation of banks in lending to the real sector of the Russian economy, considers the key features of lending to the construction industry. A number of measures are proposed, both at the macro and the micro level, ensuring not only the coherence of the economic interests of companies and banks, but also significantly reducing costs.
\end{abstract}

\section{Introduction}

The development of construction and other sectors of the real economy is extremely important for ensuring the growth of the entire national economy. And since the growth of the well-being of all economic entities depends on this, all of them should contribute to the development and positive dynamics of this process as much as possible. Growth requires cash, which is the main source of investment in expanded reproduction and construction, which is the source of economic growth.

The main institution that works with money in the economy is banks. They serve the monetary turnover of companies working in the construction sector and other sectors of the real economy that make up its nonfinancial sector, and also serve as one of the sources of investment for them, which are provided in the form of Bank loans.

Analyzing the debt structure of the non-financial sector, it can be noted that domestic borrowing is $70 \%$, having increased by $5 \%$ since 2013 . The share of loans in the domestic borrowing system has decreased slightly, but today it reaches $84 \%$. At the same time, the rubledenominated debt accounts for more than $65 \%$ of the non-financial sector's domestic borrowings, which once again highlights the relationship between the banking sector and the real economy.

The volume of loans provided by banks to legal entities and individual entrepreneurs, which make up the real sector of the economy, has a positive trend in the long-term perspective. Over the past 10 years, in absolute terms, it has grown more than 3.65 times (from 1,502,062 million rubles in March 2010 to 5,485,236 million rubles in March 2020).

At the same time, in the dynamics of loans over 10 years, the volume of loans issued has significant fluctuations during the year. This is more clearly and clearly visible on the chart in a shorter time interval. Of course, this is determined by the seasonal nature of activity, taking into account the peculiarities of the geographical location of the Russian Federation and the length of its borders, as well as the features of the economic cycle of enterprises in the real sector of the economy.

These fluctuations are related to the seasonality of business in the main sectors of the economy and the seasonal need for investment in the form of Bank loans in the maintenance and development of businesses and entrepreneurs. However, the main part of Bank loans received by enterprises is used to solve current financial

Corresponding author: masha080487@ mail.ru 
issues related to solving current production tasks, which are seasonal in many industries. To ensure the growth of the real sector of the economy, it is necessary not only to solve the current financial issues of enterprises, but also, most importantly, to invest in their fixed capital.

It should be noted that the role of banks in the process of activating investment activities of companies is extremely small. At the beginning of 2008, the share of Bank loans in the structure of investments in fixed assets was fixed at $10.4 \%$. As part of the Concept of long-term socio-economic development of the Russian Federation for the period up to 2020, adopted in 2008, it was supposed to grow by 2 times by 2020 . However, due to the global financial crisis of 2008 and its consequences, as well as due to economic sanctions imposed against Russia since 2014, banks were forced to solve their own financial problems. Therefore, by 2016, this indicator fell to $8.1 \%$, which corresponds to the level of 2006.

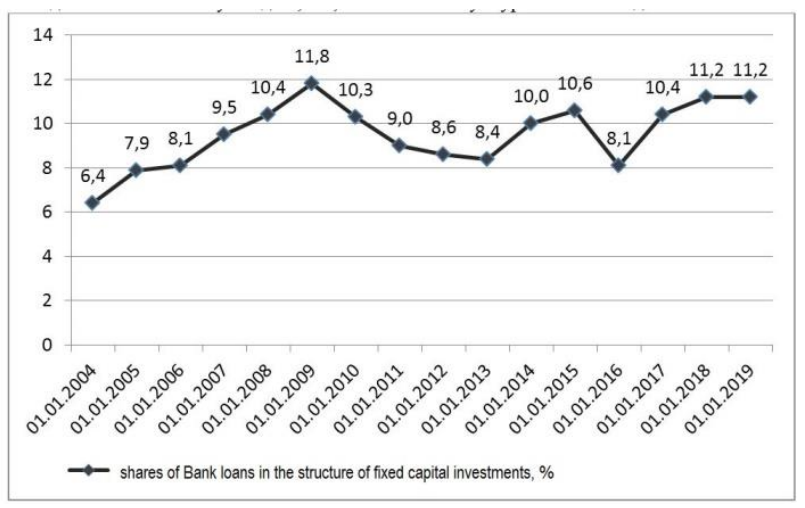

Fig. 1. Dynamics of the share of Bank loans in the structure of fixed capital investments, $\%$.

After that, according to state statistics and the Bank of Russia, the indicators of banks ' participation in the structure of investments in fixed assets have consistently increased. At the end of 2016, it reached the level of the beginning of 2008 and amounted to $10.4 \%$. At the end of 2017 , it increased to $11.2 \%$. However, in 2018 , after its reduction in the first half of the year to $8 \%$, it remained at the level of $11.2 \%$ at the end of the year.

However, it is important to take into account not only the quantitative changes in the participation of banks in the investment process, but also to monitor the qualitative changes that ensure the growth rate of individual sectors of the economy. Project financing is a tool that contributes to the development of the construction industry today. Despite the turmoil caused by the pandemic, banks confirm the stability of the situation with the financing of developers who switched to escrow accounts.

\section{Methods}

Bank loans failed to play the role they were assigned in increasing the share of investment in fixed assets of enterprises and thus ensuring the conditions for growth of the real economy. To solve these problems, enterprises are increasingly forced to rely on their own resources and resources.

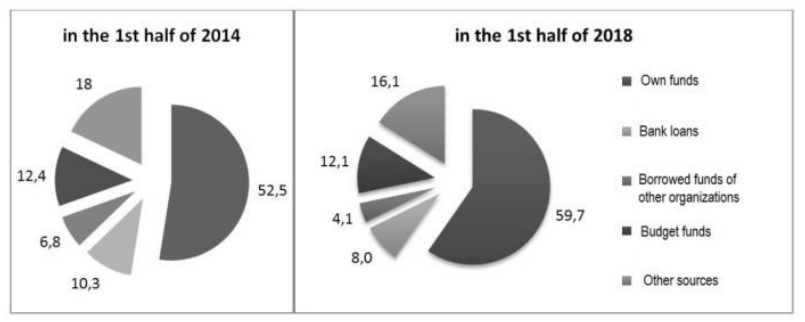

Fig. 2. the Structure of investments in fixed capital, $\%$.

The share of equity in investments increased in the first half of 2018 compared to the first half of 2014 by $7.2 \%$ (from $52.5 \%$ to $59.7 \%$ ). In this regard, enterprises began to invest less in other enterprises and the share of borrowed funds from other enterprises in the investment structure decreased from $6.8 \%$ to $4.1 \%$. the Share of budget funds remained at a level slightly higher than 12 $\%$, since budget funds are also directed to solving other problems that are often more acute.

The share of Bank loans in this indicator decreased from $10.3 \%$ to $8.0 \%$ over the specified period. This happened for several reasons.

First, as mentioned above, banks were dealing with their own financial difficulties caused first by the global financial crisis in 2008, and then by the economic sanctions imposed in 2014.

Second, it has become very burdensome for many companies to take out Bank loans. This is due to the fact that loan rates rose sharply in December 2014 following the increase in the key rate. After that, they gradually change in the direction of reduction, following changes in the key rate. At the same time, many organizations are forced to spend their profits, and often take out new loans to repay their previously taken loans and interest on them at high rates.

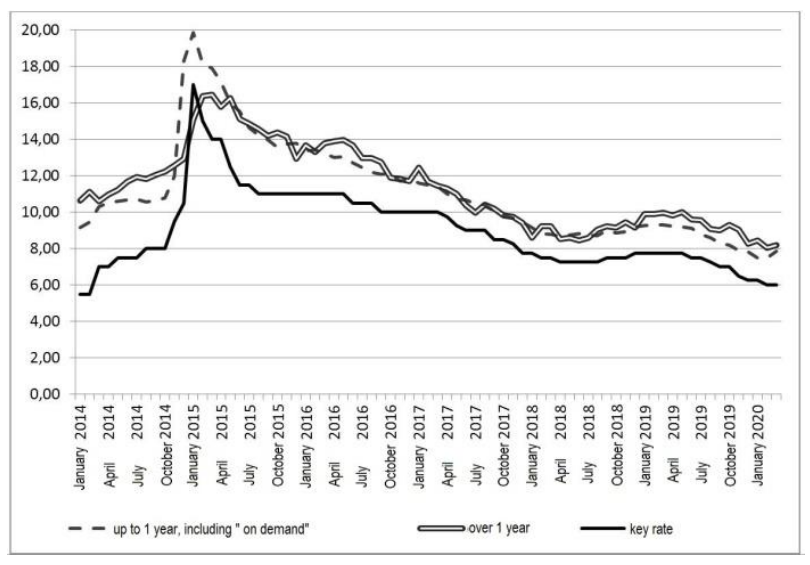

Fig. 3. weighted Average rates on loans to non-financial organizations in rubles, $\%$ per annum.

In addition, along with the reduction in loan rates, the profitability of most enterprises also decreased due to the economic downturn in the country and the reduction in real incomes of both the population and the enterprises themselves. In this regard, many companies cannot take 
out large and long-term loans necessary to invest in their development, even at the currently reduced rates.

Third, due to the above-mentioned financial difficulties, along with the growth of loan arrears, the volume of overdue loans and their share in the total amount of debt is also growing. The first jump in the share of overdue debt occurred in early 2009 and is related to the economic consequences of the 2008 crisis. The second, which occurred in early 2015, is related to the introduction of economic sanctions in 2014, which essentially blocked the possibility of receiving investment from abroad.

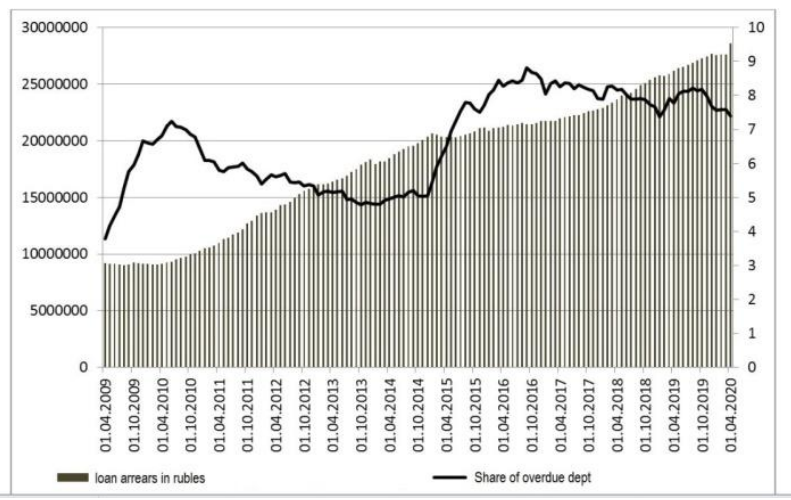

Fig. 4. Volume and structure of debt on loans to legal entities in ruble.

Despite the fact that after this, the share of overdue loans began to decrease, in 2019 it began to grow again. In this regard, banks were forced to tighten requirements for potential borrowers, which made it more difficult for them to obtain new loans, especially for a long time in conditions of economic uncertainty. This had the expected effect and the share of overdue debt began to decrease starting from the end of 2019. And all this is happening against the background of a serious reduction in the key rate, which in April 2020. it was 5.5\%. It would seem that everything is being done to make the main sources of funding cheaper and reduce the burden of interest payments on loans. Apparently, the solution to this issue lies not only in the field of monetary regulation, and it is worth paying attention to the issues of investment attractiveness of enterprises in the real sector of the economy. In this regard, Russian companies must first meet the regulatory values of financial stability indicators and increase the parameters of business value. It is not possible to implement this task for the majority of small and medium-sized enterprises due to the unsatisfactory balance sheet structure and the threat of bankruptcy.

Fourth, the reduction in the number of banks in connection with the process of clearing the Russian banking system of unscrupulous players conducted by the Bank of Russia does not contribute to the growth of the use of Bank loans as a source and method of supporting the growth of the real sector of the economy. First of all, this applies to small banks, which, according to the Bank of Russia's plans, should focus on lending to small and medium-sized businesses.
In this regard, it is necessary to solve the problem of finding effective mechanisms to stimulate the banking sector to support the real sector of the economy and stimulate its growth, while creating conditions for the development of the internal potential of Russian companies. Successful implementation of this task is possible if there is sufficient investment attractiveness of Russian companies. This requires not only consistency of economic interests of banks and organizations, but also a healthy investment climate. The investor should see the immediate prospect of implementing their projects. It provides stable profit indicators for the company, which means stable sales markets provided by effective demand and healthy competition.

It is also important to take into account that the process of interaction between banks and enterprises is associated with a high degree of risk, which requires new integrated approaches to risk management. As a condition for expanding effective Bank lending to the real sector, a reduction in credit risk should be assumed. An effective system of internal banking control plays an important role in ensuring that the interests of enterprises and banks are aligned.

The modern organization of the Bank lending system creates unequal conditions for commercial and industrial enterprises. Those areas of business where the cost of paying interest on a loan can be transferred to buyers of services, while taking into account the high turnover of working capital, contribute to an increase in the interest rate. For industrial enterprises, this policy becomes ruinous. As a result, such business areas as trade, mining, as well as the production and distribution of water, gas, and electricity in General can afford to take out a loan in the current conditions. As a result, industrial enterprises lose their ability to organize the reproduction process and reduce their competitiveness. In this regard, a well-thought-out state industrial policy is necessary. In the framework of the implementation of such policy banks should use a differentiated approach to the loan. In particular, the interest rate should vary depending on the object of lending. Such a role can be performed by development institutions today, performing certain tasks within the framework of national projects, including providing the opportunity to saturate the economy with long-term money that banks do not have. In any case, the algorithm of interaction between banks and development institutions should already take into account interest rate differentiation.

\section{Results}

Considering the mechanisms for stimulating the involvement of banks in lending to the real sector of the economy and supporting its growth, we see the following tasks that need to be solved at the micro level:

- introduction of a wide range of Bank refinancing mechanisms, including those that take into account existing foreign and domestic experience;

A number of Central banks have experience in providing banks with so - called "economic" loans, which are secured by the obligations of real sector 
enterprises (bills of exchange and credit requirements of enterprises) along with the usual type of security of the first category (highly liquid securities-government securities, as well as securities listed on major stock exchanges, etc.). Such loans are provided to banks by Central banks of a number of European countries (Germany, France), the United States and other developed countries. Implementation of this practice will require an adequate legal framework and an extensive system of institutions that are responsible for the implementation of collateral rights and the liquidation of enterprises. The experience of such lending is available in Russia. However, it requires wider application.

- formation of a system for monitoring collateral for loan debt;

The list of objects can be expanded for high-tech companies in terms of using intellectual property objects (IPOs) as collateral. Given that the value of an IPO can be much higher than the value of the entire enterprise's property-equipment, raw materials, current stocks of finished products, and in some cases may even correspond to the value of the company, this object can now freely act as a collateral instrument. It is also necessary to take into account the fact that the IPO pledge is almost the only security tool for start-up hightech companies today. In this case, the collateral agreement must function in conjunction with the loan agreement. Moreover, the pledge agreement must clearly define the point about whether the exclusive right to the result of intellectual activity is pledged, and to what extent. Moreover, the subject of the pledge agreement itself must be determined as accurately and correctly as possible. Exclusive rights to a particular item may consist of separate entitlements. To do this, a whole Institute of assessment and admission to the use of various OIS should be created.

Providing loans secured by the obligations of enterprises will require significant work to collect and evaluate data on enterprises whose obligations can be accepted as collateral for a Bank of Russia loan. In this regard, it is necessary to create a database on organizations in the non-financial sector for refinancing banks against the obligations of enterprises. It is possible to form a so-called "collateral pool" that is actively used abroad.

- reengineering of companies ' business processes;

The need to develop project financing is associated with the implementation of the long-term lending process. In this regard, the introduction of Bank representatives in the management of funded organizations will not only make it possible to organize the credit process more efficiently, but also ensure the rational functioning of the business in the company. It is also possible for the Bank to join the capital of financed enterprises and thus create financial and industrial groups, the success of which is confirmed by both Russian and foreign experience. This can be a solution to bad debts and at the same time revive real production.
Emerging FGS will be a conglomerate (vertical or horizontal) in terms of production and economic integration, intersectoral in terms of industry affiliation, multidisciplinary in terms of diversification, and regional in terms of scale of activity. At the same time, banks are becoming even more involved in the work of enterprises in the real sector of the economy, and therefore interested in their growth. However, it is necessary to work out the banking legislation regarding restrictions on lending by banks to affiliated entities.

- use of new financial instruments;

In accordance with the procedure for applying the new tool, equity holders ' funds will be accumulated in special Bank accounts-escrow. The developer will be able to use the money of shareholders only after the construction is completed. Thus, banks will lend to the developer and their role in ensuring the development of the construction industry will increase. This scheme will significantly change the financing mechanism of the construction industry. Major banks prepare products for project lending to developers based on the use of flexible interest rates and convenient credit conditions.

The result of implementing this tool is that a third of the housing under construction in Russia is now sold through escrow accounts. Today, more than $90 \%$ of applications received by Sberbank from developers are applications for project financing with escrow. The possibility of using escrow accounts revealed a serious contradiction in the pricing system, where banks take the position of restraining the growth of the price per square meter, stimulating demand.

- reducing the number of documents requested by the Bank from the borrower;

The list of documents requested by the Bank must comply with the basic principles of lending, without reducing the ability of the borrower to take out a loan. In addition, these documents should provide a qualitative assessment of the borrower's creditworthiness in accordance with the requirements of the Bank of Russia, both for issuing loans and for creating reserves for them. This is especially true for long-term loans and loans to small and medium-sized businesses, where the preparation and submission of the requested documents to the Bank requires distracting employees from their main activities or forces them to hire new employees, thereby increasing the company's expenses. Under these conditions, it is possible to create business centers with the support and participation of banks that can provide consulting, marketing, and audit services for enterprises in the real sector of the economy. These centers can operate on the principle of the Bank of Russia's regulatory sandbox, or even within it. In addition, electronic document management and other modern financial technologies that have been actively developed and implemented recently as part of the digitalization of the economy can be used to facilitate and reduce paper document flow between banks and borrowers. 
Table 1. System of measures to enhance interaction between enterprises and banks.

\begin{tabular}{|c|c|c|c|}
\hline Activity & Implementation tool & $\begin{array}{l}\text { Use mechanism } \\
\end{array}$ & Implementation system \\
\hline $\begin{array}{ll}\text { Bank } & \text { refinancing } \\
\text { mechanisms } & \end{array}$ & $\begin{array}{l}\text { "business" loans secured by } \\
\text { the first category }\end{array}$ & $\begin{array}{l}\text { loans are provided to commercial } \\
\text { banks by Central banks }\end{array}$ & $\begin{array}{l}\text { development of a regulatory } \\
\text { framework and an extensive } \\
\text { system of institutions for the } \\
\text { implementation of collateral } \\
\text { rights and liquidation of } \\
\text { enterprises }\end{array}$ \\
\hline $\begin{array}{l}\text { the system for monitoring } \\
\text { collateral for loan debt }\end{array}$ & $\begin{array}{l}\text { intellectual property } \\
\text { objects (IPOs) as collateral }\end{array}$ & $\begin{array}{l}\text { the collateral agreement should } \\
\text { function in conjunction with the loan } \\
\text { agreement }\end{array}$ & $\begin{array}{l}\text { creation of the Institute for } \\
\text { assessment and admission } \\
\text { to the use of various IPOs }\end{array}$ \\
\hline $\begin{array}{l}\text { reengineering of business } \\
\text { processes of companies }\end{array}$ & creating a FPG & $\begin{array}{l}\text { entering the Bank's capital of funded } \\
\text { enterprises }\end{array}$ & $\begin{array}{l}\text { development of banking } \\
\text { legislation in terms of } \\
\text { limiting lending by banks to } \\
\text { affiliated entities }\end{array}$ \\
\hline $\begin{array}{l}\text { reducing the number of } \\
\text { documents requested by } \\
\text { the Bank from the } \\
\text { borrower }\end{array}$ & $\begin{array}{l}\text { electronic document } \\
\text { management }\end{array}$ & $\begin{array}{l}\text { creating business centers with the } \\
\text { support and participation of banks }\end{array}$ & $\begin{array}{l}\text { introduction of modern } \\
\text { digital technologies } \\
\text { improvement of legislation }\end{array}$ \\
\hline $\begin{array}{l}\text { development of } \\
\text { partnership relations } \\
\text { between banks and the } \\
\text { business community }\end{array}$ & $\begin{array}{l}\text { financing of start-UPS by } \\
\text { banks }\end{array}$ & $\begin{array}{l}\text { development of partnership relations } \\
\text { between banks and business } \\
\text { incubators }\end{array}$ & $\begin{array}{l}\text { development of interaction } \\
\text { mechanisms }\end{array}$ \\
\hline $\begin{array}{l}\text { formation of long-term } \\
\text { funding sources }\end{array}$ & $\begin{array}{l}\text { mechanism for banks ' } \\
\text { access to long-term funding } \\
\text { sources }\end{array}$ & $\begin{array}{l}\text { access of banks to free funds of the } \\
\text { state, state corporations, pension } \\
\text { funds and insurance companies }\end{array}$ & $\begin{array}{l}\text { разработка механизмов } \\
\text { взаимодействия }\end{array}$ \\
\hline
\end{tabular}

- development of banks ' partnership with the business community and relations with society as a whole;

The development of partnership relations between banks and business incubators will contribute to more active involvement of banks in lending and financing of start-UPS, which are now drivers of economic growth in many countries and are actively gaining momentum in Russia. Their lending under the current legislation and banking rules is very difficult, since they have no financial history or any security, but only ideas and a desire to implement them. Therefore, we need to correct the current legislation in this direction.

- formation of long-term funding sources;

In addition to attracting funds from private investors, as mentioned earlier, it is necessary to work out a mechanism for banks ' access to long-term sources of financing, such as free funds from the state, state corporations, pension funds and insurance companies. This will allow banks to manage resources more boldly and confidently, giving businesses more long-term loans, which is important for businesses to invest in their future development and growth.

Summarizing the above, the system of measures to enhance interaction between banks and companies can be presented in the following form (table 1).

Participation of banks in various public programs that are not purely commercial, but also social and cultural in nature will help to improve the attitude towards banks and increase confidence in them. And thanks to this, banks will be able to actively develop cooperation with enterprises and citizens, attracting money from them and providing loans to enterprises and individual entrepreneurs, which will contribute to the development and growth of the real economy.

\section{Discussions}

Given that the task of stimulating the growth of the real sector is not only for the banking system, but also for the entire Russian economy as a whole, the approach to its solution should be comprehensive and systematic at different levels.

At the macro level, there are several ways to solve the problem of stimulating the growth of the real sector of the economy.

It seems appropriate to involve banks more actively in the implementation and financing of national projects. It is necessary to make banks active participants in the implementation of national, as well as related Federal and regional projects. The level of the program that the Bank is involved in should be linked primarily to the Bank's financial capabilities. At the same time, it makes sense to consider the Bank's participation in a particular project individually, taking into account, in addition to its financial capabilities, its role in the region's economy, territorial, cultural and historical features. In addition to servicing the enterprises involved in these projects, banks need to be involved in financing these enterprises. Moreover, this funding should be based on the principles of public-private partnership (PPP). In other words, part of the money will be allocated to banks from the Federal or local budget that finances the project, and placed in the Bank for further lending to real sector enterprises within the project. And the banks will have to allocate the other part from their own funds. Thus, banks become interested in the successful implementation of the project and the growth of the real sector of the economy directly or indirectly associated with it. At the same time, the state, represented by the Ministry of Finance, the Bank 
of Russia and other interested Federal bodies, should provide a clear system for monitoring and managing projects and related risks.

One of these projects is the national project "Housing and urban environment", approved in December 2018. Its main key goals are to provide affordable housing for middle-income families, increase the volume of housing construction, improve the comfort of the urban environment, reduce the housing stock that is unsuitable for housing, etc. This will contribute to the growth of the welfare and housing conditions of Russian citizens, and will be achieved through the development of construction and other related industries.

It is also possible to work out issues on granting tax and other benefits to banks that lend to enterprises from priority sectors of the economy. Moreover, this lending can be carried out by banks as part of participation in the financing of national, Federal and regional projects, or completely at their own expense.

Another issue of stimulating the banking sector to support the growth of the real economy, which needs to be addressed at the macro level, is the creation of a favorable and trust-based economic environment. The scale of investment in the real economy and its development in the market economy of the West relies on an army of institutional investors, financial intermediaries the network of financial markets, carefully designed legislation and developing for many decades-way trust of wide layers of private investors (i.e. of the population) to all named institutions. Private investors, especially in the context of economic sanctions and the closure of foreign sources of financing, should become an important source of financing for the growth of the real economy. This financing should be carried out through various financial institutions, including banks, which should turn the funds of private investors placed with them into loans to the real sector of the economy. Therefore, the state should create legislative conditions that will help increase the confidence of private investors in banks. To do this, in particular, the Bank of Russia should set time limits for completing the active process of improving the Russian banking sector and clearing it of unscrupulous players, and establish clear and understandable criteria for classifying banks as such players. This will increase confidence in the banking system as a whole, since neither private investors nor businesses in the real sector will be afraid to cooperate with a particular Bank for fear of revoking its license.

To form a comprehensive mechanism for active involvement of banks in the lending process and support the growth of the real economy, it is necessary to combine regulatory and tax incentives, as well as a set of measures aimed at reducing investment and credit risks.

\section{References}

1. Anna A. Vershinina, Liudmila V. Goryainova, Olga A. Zhdanova, Tatiana P. Maksimova, Journal of Internet Banking and Commerce. Special Issue: Finance, Services Sector and Commerce:
Innovations and Investments. State of the Investment Fund Market of as an Indicator of the Country's Socio-Economic Development, 21, 3, (2016)

2. Anna A. Vershinina, Olga A. Zhdanova, Tatiana P. Maksimova, Denis G. Perepelitsa, International Journal of Economics and Financial Issues. The formation of indicator framework for effective assessment of investment attractiveness of the region 5(3), 136-141 (2015)

3. L. Chicherova, Banks or equity holders: which financing is best for developers now https://www.vedomosti.ru/realty/articles/2020/05/13 /830137-banki-ili-dolschiki (2020)

4. David H. Pyle - Haas School of Business, University of California, Berkeley. Conference of Risk management and regulation in banking Bank Risk Management: Theory. Jerusalem, May 17-19, (1997)

5. G. Akerlof, M. Spence, J. Stiglitz: problemes Econ. P. l'asymetrie au coeur de la nouvelle microeconomie. N 2734.1924 (2001)

6. C. James, The Wharton Financial Institutions Center, University of Pennsylvania. RAROC based capital budgeting and performance evaluation: a case study of bank capital allocation. Working paper, 96-40 (1996)

7. Joel Bessis Wiley Publishing, Risk Management in Banking. Third edition (2010)

8. Jonathan McMillan, The End of Banking: Money, Credit, and the Digital Revolution Corpus, 256 (2019)

9. I. Keri, E. Gromova, N. Sinelschikova, The EUrASEANs: Journal on Global Socio-Economic Dynamics, Features of the development of financial policy of russian companies in modern conditions, 4 (11), 38 (2018)

10. Meyer Aaron, Jim Armstrong, and Mark Zelmer. An Overview of Risk Management at Canadian Banks. (2006)

11. O. Merkulova, Banks and developers are embracing a new reality. https://expert.ru/south/2019/03/bankii-zastrojschiki-osvaivayut-novuyu-realnost/ (2019)

12. Michael Hudson, The bubble and beyond: fictitious capital, debt deflation and the global crisis, (2012) https://michael-hudson.com/2012/07/the-bubbleand-beyond/

13. Omar Costa, Jawad Khan, and Alfonso Natale, USA: McKinsey \& Company. Rethinking bank risk in emerging markets., September (2014)

14. D.I. Stepanova, S.S. Hasanova, L.M. Allanina, B.I. Skorodumov, A.V. Novikov, International Journal of Innovative Technology and Exploring Engineering.. Digital technologies in the global economy: Technologies and innovations, 8(8), 2775 (2019)

15. Stiglitz Weiss Lecture notes 10-12 it's about credit rationing. (1981) 
16. O.V. Takhumova, M.A. Kadyrov, E.V. Titova, D.S. Ushakov, M.I. Ermilova, Capital structure optimization in Russian companies: problems and solutions, Journal of Applied Economic Sciences, Vol. XIII. Issue 7 (61), 1940 (2018)

17. V.V. Zozulya, E.V. Altukhova, V.I. Pyatanova, O.V. Romanchenko, Effective Management Of Financial Assets Of The Company As The Factor Of The National Economy Development, International Journal of Advanced Science and Technology 29(9), 2651 (2020). 